\title{
REGENERATION OF INDUSTRIAL HERITAGE IN TERMS OF SUSTAINABLE TOURISM DEVELOPMENT
}

DOI: http://dx.doi.org/10.18509/GBP.2015.60

UDC: 338.484/502.131.1]/725.1/66(497.113),17/20“

\author{
Ass. Prof. Dr. Nevena Ćurčić \\ Doc. Dr. Vuk Garača \\ Doc. Dr. Svetlana Vukosav \\ Doc. Dr. Milan Bradić
}

University of Novi Sad, Faculty of Sciences, Department of Geography, Tourism and Hotel

Management, Novi Sad, Serbia

\begin{abstract}
Industrial heritage is a specific form of heritage of human society, which emerged as the product of industrialisation, i.e. as the by-product of deindustrialisation of the society, when certain objects were abandoned. In Vojvodina encountered numerous areas of industrial heritage some of which date from the 18th century. The aim of the research is to find ways to preserve existing industrial heritage regeneration through tourism, to propose the development of tourism activities on the sites, individual buildings or entire landscapes, and at the same time through the placement of industrial heritage tourism generates economic productivity. The paper used a comparative method, analysis and synthesis, application of the concept of sustainability. In this sense, the industrial heritage tourism in Vojvodina would define interesting new combination of quality tourism products to the preservation and promotion of regional identity and authenticity of partial elements, with the removal of prejudices towards unusableness old industrial zones.
\end{abstract}

KEYWORDS: Industrial heritage, regeneration, tourism products, sustainable development

\section{INTRODUCTION}

Industrial heritage is a specific form of human society's legacy which emerged as a consequence of industrialisation, i.e. of the deindustrialisation of the society and of the shutting down of many production facilities and factories [1]. The process of deindustrialisation resulted in many negative consequences: the loss of jobs and the increase of unemployment, the decline of large urban regions, the demographic changes (depopulation). These phenomena are particularly conspicuous in transition countries, where entire industrial complexes and zones have been abandoned, and facilities are most frequently left to decay. Moreover, industrial heritage is considered to be ugly and bleak, whereas the industrial landscape is just a painful memory of the country's former economic growth and development.

»But industrial tourism has become increasingly popular in recent years. Attitudes towards industrial history have changed during the last two decades and industrial civilization has become something to conjure up - in many terms woven into spatial policy issues and research demands: regeneration of devastated areas, conservation, and tourism development « [2]. The development of industrial tourism is a new chance to restore the use value of industrial facilities, to breathe new life and give new function to these (historical) facilities, and to draw the local/regional/national authorities' attention to the 
necessity of protection and preservation of historical industrial facilities. In this way, industrial facilities become the essential foundation for the development of innovative tourism products related to industrial heritage and successful modern tourism products.

\section{HISTORICAL CONTEXT INDUSTRIAL HERITAGE IN VOJVODINA}

From the historical perspective, the development of the industry has always been associated with the greater availability of input, and with the traffic infrastructure and uninterrupted transport both to the factories and to market places. Inputs are the resource basis for the development of certain forms of industry branches and are partly conditioned by natural factors and resources.

From the geographical perspective, Vojvodina is a predominantly agricultural region. Agricultural production emerged from the fertile plough land, abundant water resources and the moderate continental climate. Vojvodina comprises $35 \%$ of Serbia's agricultural land area. Its arable land accounts for 39\%, and its ploughland for 47\%. This is an average of 0.82 hectares per capita of arable land, and 0.89 of agricultural land, which is significantly more than it is the case with the Republic of Serbia, where the corresponding values stand at 0.47 and 0.57 hectares [3]. It is therefore not surprising that the highest number of industrial companies is linked exactly to agricultural products and their processing, even though construction companies and those pertaining to mechanical engineering, chemical industry, mining and other fields are present as well. Company structure in Vojvodina, according to their commercial activities is as follows: mills, food industry, hemp industry, construction, mechanical engineering, chemical industry, power stations, textile industry, leather industry, technological industry, wood processing, mining.

A. The oldest industrial facility on Vojvodina's territory, constructed in 1722 in Pančevo, is a street building with the central part in the shape of a tall tower, i.e. a chimney. The building of the national brewery (previously owned by Đorđe Vajfert) in Pančevo is a complex of facilities constructed in the period between 1722 and the beginning of the $20^{\text {th }}$ century. Today, the facility is devastated and some of its parts are prone to collapsing. It is currently undergoing the facility reconstruction procedure and is being put into operation by the creative industry.

B.

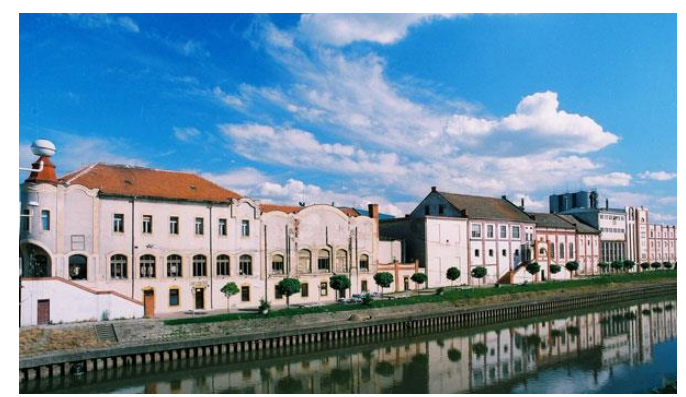

Image 1 The building of the Dunđerski Palace with the brewery complex [4]

The following industrial facility was erected in 1745, when Sebastijan Kracajzen opened the first industrial plant for beer brewing in Zrenjanin. The $18^{\text {th }}$ and $19^{\text {th }}$ centuries' industrial architecture of the brewery complex is no longer extant, and the new brewery in its vicinity was erected by Lazar Dunđerski in 1911 (Image 1). This brewery had been operational for nearly a century (with technological innovations), when following privatisation it quickly entered bankruptcy proceedings (from 2003 to 2006), and the 
facility was shut down and left to the ravages of time. With little effort, it is possible to start brewing beer in it again, to open a museum, a brewing trade school, and to preserve the brewery's tradition (it is currently undergoing procedure to be proclaimed a cultural heritage monument) [4].

The two listed examples are just an illustration of Vojvodina's great potential with regard to industrial heritage, and to the relatively preserved state of the facilities, plants and equipment which could become interesting and substantive tourist sites with minimal investment.

\section{SUSTAINABLE DEVELOPMENT OF INDUSTRIAL HERITAGE}

The industrial facilities from the earlier eras which are extant today in Vojvodina can be observed relative to the time periods when they were constructed. Thus we perceive three moments crucial to the development of industrial facilities:

1. The period before the First World War, Vojvodina as part of the Austro-Hungarian Empire,

2. The period between the First and the Second World War, Vojvodina as part of the Kingdom of Yugoslavia,

3. The period after the Second World War, Vojvodina as part of the Socialist Federal Republic of Yugoslavia, Federal Republic of Yugoslavia, Republic of Serbia.

The period of transition and changes to the ownership structure, which has been particularly intensive since 2001 in Vojvodina and Serbia, brought about many changes to the industrial sector ${ }^{62}$. Companies passed from social, mixed and cooperative ownership into private ownership [5]. New company owners were not completely interested to maintain the existing industrial production, and so many facilities were shut down or their intent was changed. Changes to the usability of the facilities have often been made to the detriment of the very facilities, plants and equipment, as they were most frequently transformed into warehouses and storage space or are only partially operational and are being used for small-scale manufacturing and processing (car repair, carwash, product packaging, mini drying plants and other). Parts of facilities which are non-operational are left to decay, and some are even torn down to extract at least a small economic benefit from the sale of used building materials so as to secure the economic survival of the new owners. Old machines and plants which have great historical and museum value are frequently cut and sold as scrap metal. The lack of capital and the economic hardships of Serbia in general, which have gained particular momentum since 2008 and the occurrence of the Global Financial Crisis, forced the new owners to resolve their survival on the market in this manner which is extremely destimulating to the economy.

\footnotetext{
${ }^{62}$ Privatisation is the key part of property transformation, as an important component of total transition, and it implies the passing of the state and social property structure into private ownership. The process of ownership transformation in Serbia commenced in the early 90's of the $20^{\text {th }}$ century, in accordance with the former federal regulations [6]. According to the Privatisation Law, which was passed in 2001, (the new Law was passed in 2014), approximately 2500 companies were privatised, and approximately 2.6 billion euros collected.
} 


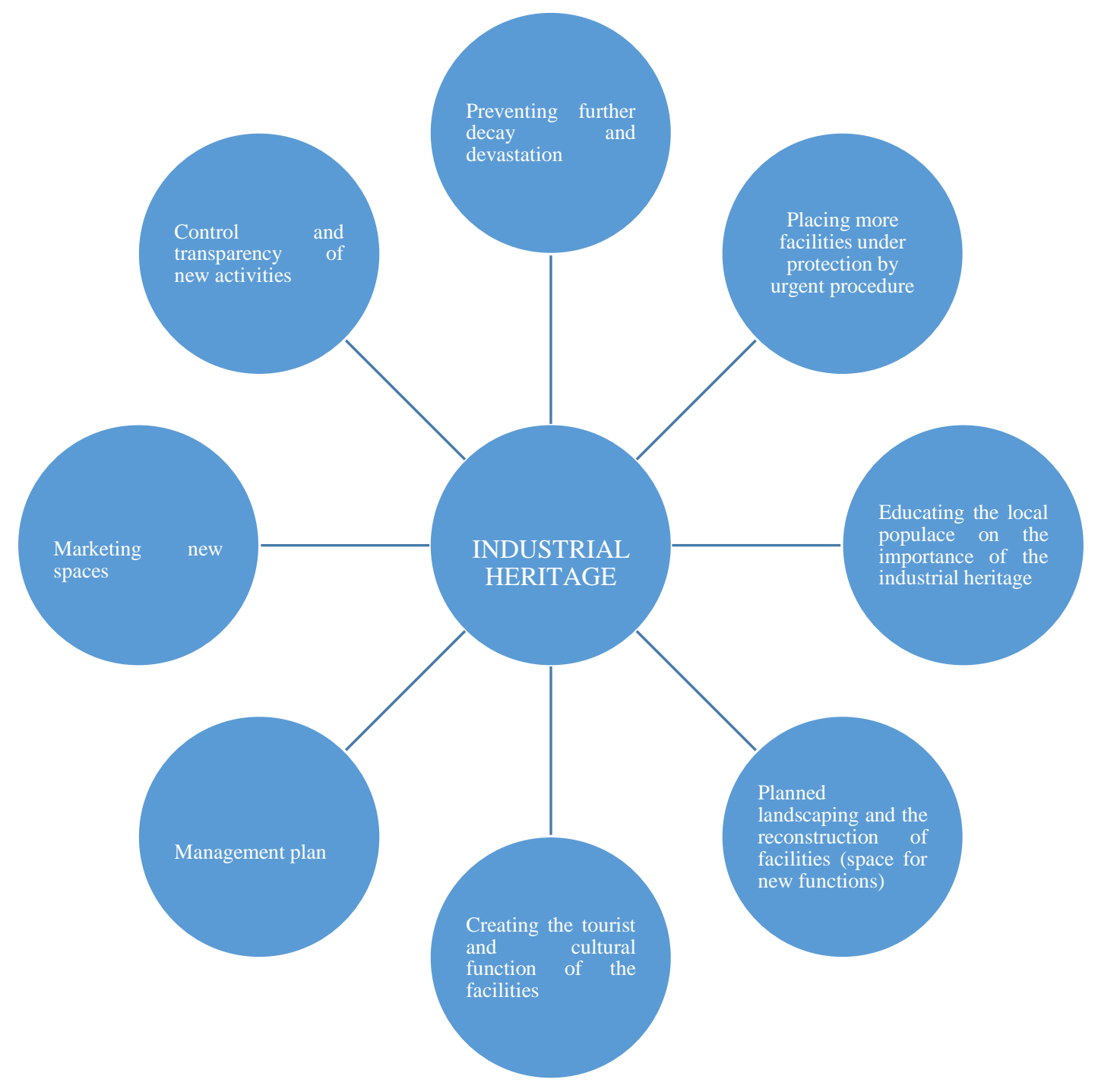

Graph 1 Procedures for the preservation and fostering of industrial heritage (Source: authors)

A solution for the survival, preservation, functional and sustainable growth (social, cultural and economic) of the industrial heritage facilities should be sought in the various modalities of the repurposing of space and its involvement in tourism (Graph 1). These facilities may offer special ambience, content and function by means of their transformation into exhibition or museum space, i.e. into the facilities of cultural tourism (Table 1). »Beyond the actual difficulties of remodeling for tourism (big investments, poor social consideration, abandoned buildings of little monumental potential, neglected landscapes in the area, etc.) a very wide range of museums that can be divided into 4 main types:

1. cultural centres, exhibit permanent or temporary collections, of an artistic or other variety, in renovated industrial buildings as an evocative and fascinating framework. These are the industrial heritage museums with the greatest number of tourist visitors.

2. performance centres, explain the industrial area completely, with the technical and architectural elements that make up a determinate production process. In these 
museums great importance is given to the heritage value of the collections and buildings.

3. ecomuseums, facilitate understanding of the industrial or mining impact on a wide area and allow the tourist to understand various heritage elements that are interrelated. These museums show the advantage of offering a global image but their size obliges the establishment of more or less organized visit routes.

4. thematic museums, explain the logic of a determinate production, or of a specific aspect of the industrialization of an area. The content focuses broadly on explanatory interest and the specific knowledge of the old production process confers a high didactic value on this category of industrial museums « [7].

Table 1 Industrial heritage museums in Vojvodina

\begin{tabular}{|c|c|c|c|c|c|}
\hline Object name & Place & Museum & $\begin{array}{c}\text { Construction } \\
\text { time }\end{array}$ & $\begin{array}{l}\text { The formation } \\
\text { of the museum }\end{array}$ & $\begin{array}{l}\text { Available for } \\
\text { visits }\end{array}$ \\
\hline $\begin{array}{l}\text { The complex } \\
\text { of brewery }\end{array}$ & Zrenjanin & $\begin{array}{l}\text { thematic } \\
\text { museum }\end{array}$ & 1911 & In the process of & Only pub \\
\hline $\begin{array}{l}\text { Brewery of } \\
\text { Čelarevo - } \\
\text { Carlsberg }\end{array}$ & Čelarevo & $\begin{array}{l}\text { performance } \\
\text { centre }\end{array}$ & 1892 & $\begin{array}{l}\text { 2003, Brewery } \\
\text { Museum }\end{array}$ & Yes \\
\hline $\begin{array}{l}\text { Castle } \\
\text { Stratimirović }\end{array}$ & Kulpin & $\begin{array}{l}\text { performance } \\
\text { centre }\end{array}$ & 1826 & $\begin{array}{c}1993, \\
\text { Agricultural } \\
\text { Museum }\end{array}$ & $\begin{array}{l}\text { After the } \\
\text { announcement }\end{array}$ \\
\hline $\begin{array}{l}\text { »Imperial } \\
\text { brewery « }\end{array}$ & Apatin & $\begin{array}{l}\text { thematic } \\
\text { museum }\end{array}$ & 1756 & - & No \\
\hline $\begin{array}{l}\text { National } \\
\text { brewery }\end{array}$ & Pančevo & cultural centre & $\begin{array}{l}\text { from } 1722 \text { to } \\
\text { the early } 20 \text { th } \\
\text { century }\end{array}$ & In the process of & No \\
\hline $\begin{array}{l}\text { Weaving silk } \\
\text { damask }\end{array}$ & Bezdan & $\begin{array}{c}\text { performance } \\
\text { centre }\end{array}$ & 1871 & Visits weaving & $\begin{array}{l}\text { After the } \\
\text { announcement }\end{array}$ \\
\hline $\begin{array}{l}\text { Velikokiki- } \\
\text { ndski steam } \\
\text { Mill }\end{array}$ & Kikinda & $\begin{array}{l}\text { thematic } \\
\text { museum }\end{array}$ & 1869 & - & No \\
\hline Suvača mill & Kikinda & $\begin{array}{l}\text { thematic } \\
\text { museum }\end{array}$ & 1899 & Mill & Yes \\
\hline $\begin{array}{l}\text { Wine cellar } \\
\text { Helvecia }\end{array}$ & Vršac & $\begin{array}{l}\text { thematic } \\
\text { museum }\end{array}$ & 1880 & $\begin{array}{l}\text { Visits to the } \\
\text { cellar }\end{array}$ & Yes \\
\hline SL Brewery & Vršac & restaurant & 1720 & $\begin{array}{l}\text { A small part of } \\
\text { the exhibition at } \\
\text { the pub }\end{array}$ & Only pub \\
\hline Wine cellars & Čoka & $\begin{array}{l}\text { thematic } \\
\text { museum }\end{array}$ & 1903-1912 & $\begin{array}{l}\text { Visits to the } \\
\text { cellar }\end{array}$ & Yes \\
\hline $\begin{array}{l}\text { The lock on } \\
\text { the canal } \\
\text { Dunav-Tisa- } \\
\text { Dunav }\end{array}$ & Bečej & $\begin{array}{l}\text { performance } \\
\text { centre }\end{array}$ & 1899 & $\begin{array}{c}\text { Water } \\
\text { management } \\
\text { facility }\end{array}$ & $\begin{array}{l}\text { Yes, After the } \\
\text { announcement, } \\
\text { organized } \\
\text { visits }\end{array}$ \\
\hline $\begin{array}{l}\text { Museum of } \\
\text { beekeeping }\end{array}$ & $\begin{array}{l}\text { Sremski } \\
\text { Karlovci }\end{array}$ & $\begin{array}{l}\text { thematic } \\
\text { museum }\end{array}$ & 1968 & $\begin{array}{l}\text { Museum of } \\
\text { beekeeping, } \\
\text { winery }\end{array}$ & Yes \\
\hline
\end{tabular}




\begin{tabular}{|c|c|c|c|c|c|}
\hline $\begin{array}{l}\text { "Jovan } \\
\text { Živanović" }\end{array}$ & & & & & \\
\hline $\begin{array}{l}\text { Museum of } \\
\text { tobacco, } \\
\text { Museum } \\
\text { blacksmith's } \\
\text { craft }\end{array}$ & Telečka & $\begin{array}{l}\text { thematic } \\
\text { museum }\end{array}$ & 2009 & $\begin{array}{l}\text { Museum of } \\
\text { tobacco, } \\
\text { Museum } \\
\text { blacksmith's } \\
\text { craft }\end{array}$ & $\begin{array}{l}\text { Yes, } \\
\text { admission free }\end{array}$ \\
\hline $\begin{array}{l}\text { Lock (Šlajz) } \\
\text { on the Danube }\end{array}$ & Bezdan & $\begin{array}{c}\text { performance } \\
\text { centre }\end{array}$ & 1856 & $\begin{array}{c}\text { Water } \\
\text { management } \\
\text { facility }\end{array}$ & $\begin{array}{l}\text { Yes, After the } \\
\text { announcement }\end{array}$ \\
\hline Rope factories & Odžaci & $\begin{array}{l}\text { thematic } \\
\text { museum }\end{array}$ & 1908 & $\begin{array}{l}\text { With workers' } \\
\text { colony in the } \\
\text { first half of the } \\
\text { twentieth } \\
\text { century }\end{array}$ & Yes \\
\hline Coal Mine & Vrdnik & ecomuseum & 1804 & Out functions & No \\
\hline
\end{tabular}

\section{DISCUSSION}

Industrial heritage is defined as the interdisciplinary method of studying the material and nonmaterial testimonies, documents, artefacts, facilities, settlements and other which were created for or by industrial processes [8]. The concept of sustainable growth can be applied to the successful regeneration of the industrial heritage. Sustainable growth is usually viewed from three aspects - of the social, cultural and economic sustainability. Apart from its testimonies of the history of technology in the period between the $18^{\text {th }}$ century's industrial revolution and now, and its potential aesthetic value, industrial heritage tells the story about life, about the day to day activities of the area in which it originated; it has sociological value as well. The size of the facilities and their construction style, the commercial activities of the facilities, the tools and plants, the traffic and transport communications, the professional profile of the workforce, their work habits and customs, and other, are a faithful historical picture of the society and its production and processing activities. Some of the industrial facilities enjoy a special degree of protection as cultural heritage. They are ethnographic objects as well, which have witnessed an era, the culture and customs of the peoples who lived and worked on Vojvodina's territory. The historical artefacts are simultaneously factors of cultural education for the visitors to the industrial heritage.

The effect of the visits and the economic sustainability - the visitors are mostly comprised of the young people on field trips, children of school age and students of relevant educational profiles. Transit tourists also come visiting as well as the organised groups of foreign and local participants of congresses, confederations, business partners, and the staff of foreign embassies and their family members. Time of stay is short: from half an hour to three hours. Tickets are either not charged or the price is symbolic (0.5-3€). Visiting price is higher if there is an organised wine, honey or beer tasting. The economic effect of such visits to these facilities is very small or more frequently insufficient for the museum to be self-sustainable.

The scope of the visits is conditioned by the very location of the museum (in the city, in the approximate vicinity of the city, outside major roads), by how attractive the exhibition is (interactivity with visitors remains underdeveloped) and by the size and number of the 
museum pieces (a large number of pieces from the earlier eras, as well as the larger pieces such as the machinery, large tools, means of transport and the like, attract a higher number of visitors). Ticket price is insufficient for the economic survival of the museums, so they should develop other means of income, such as selling souvenirs, service photographing of the visitors, providing the basic restaurant services, organising special interactive workshops or additional forms of entertainment (visitors make their own souvenirs, take part in a local custom and the like).

Urgent reconstruction and revitalisation of the industrial heritage facilities is required, as well as the landscaping around the facilities, since they are the historical pearls of past commercial activities. By means of revitalisation, industrial heritage may become a model for the preservation of the long-lasting traditional values and economic activities, a way to educate the younger generations and a significant avenue for new developments in tourism. In this manner huge complexes in industrial zones or individual commercial facilities will be recovered from decay, and destinations will gain new attractive content and will therefore be called "landscapes of nostalgia".

\section{CONCLUSION}

The growing competition on the market demands constant innovations to the tourist product. Vojvodina's chance to develop tourism is the finding of the relevant market niches and creating wholly new tourism products. In this manner, diversification of tourism products is increased, as well as the competitiveness of these products, and animation and interpretation gain full form thanks to the very tangible content.

The basic precondition for the preservation of the industrial heritage is definitely the education of the populace and of the owners of the industrial facilities as to the industrial heritage as an important segment of the local, national, and universal legacy, and as to its potential for commercial growth. Apart from that, there should be a strategy of preservation and management of industrial heritage at the local and state levels. Additionally, positive experience from abroad should be applied and the expert public, interested individuals and civil society organisations should be involved in the decisionmaking processes regarding the repurposing of the content of industrial heritage sites, which would definitely contribute to their preservation. Led by the positive examples from abroad, we may conclude that a well-researched and well-documented industrial heritage can easily become an important resource of tourist offer, and its proper regeneration and economic activation must be based on the sustainable growth of tourism. In that sense, the industrial heritage tourism of Vojvodina could define an interesting new combination of quality tourism products, while preserving and fostering the regional identity and the authenticity of its partial elements, and dispelling the prejudice about the uselessness of old industrial zones.

\section{ACKNOWLEDGEMENTS}

The authors would like to thank Secretariat for Science and Technological Development of Autonomous Province of Vojvodina for financially supporting this research (Project No. 114-451-1485/2014-03). 


\section{REFERENCES}

[1]Garača V., Trifković A., Curčić N. \& Vukosav S. Aspects of Industrial Heritage Tourism: Case of Novi Sad. Revista de cercetare si interventie sociala, Romania, Vol.44, pp.181-198, 2014.

[2]Pawlikowska-Piechotka, A. Industrial Heritage Tourism: a Regional Perspective (Warsaw), Physical Culture and Sport. Studies and Research, Poland, 1/2009; 46(1), pp.276-287, 2009.

[3] http://www.pkv.co.rs/book/export/html/104 (21 January 2015)

[4]http://www.zrenjaninheritage.com/kulturna-dobra/spomenici-kulture/palatadundjerski (5 February 2015)

[5]Jovanović G. Građevinarstvo, Privreda Srema II, geografska monografija, PMF, Institut za geografiju, Novi Sad, Srbija, pp.5-8, 1999.

[6]Vukosav S. \& Ćurčić N. Promene u hotelijerstvu Vojvodine kao rezultat tranzicionih procesa. Journal of the Geographical Institute „Jovan Cvijić“ SASA, Serbia, Vol.59, No.1, pp.111-126, 2009.

[7]Pardo Abad, J., C. The Industrial Heritage In Spain: Analysis From A Tourism Perspective And The Territorial Significance Of Some Renovation Projects, Boletín de la Asociación de Geógrafos Españoles, Spain, N N. 53 - 2010, pp. 401-404, 2010.

[8]Kulenović R. Industrijsko nasleđe Beograda, Muzej nauke i tehnike, Beograd, Srbija, pp.4-12, 2014. 